\title{
Floristic Diversity of Handüzü Natural Park and Environs, Turkey
}

\author{
Vagif ATAMOV1 ${ }^{\wedge}$ (D), Mustafa ÇOBANOĞLU2 (iD) \\ Department of Biology, Faculty of Arts and Sciences, Recep Tayyip Erdogan University, 53100, Rize-Turkey \\ ${ }^{1}$ https://orcid.org/0000-0002-6718-7979, ${ }^{2}$ https://orcid.org/0000-0002-2115-9761 \\ $\bowtie$ : vhatemov@yahoo.com
}

\begin{abstract}
The floristic diversity of Handüzü Natural Park and Environs as a protected area within Kaçkar Mountains chain, situated in Güneysu and İkizdere counties of Rize (Turkey) was studied. Overall, 517 taxa belong to 352 genera and 104 families were determined. Twenty-three of these taxa are represented in division Pteridophyta while 494 of them are in division Spermatophyta. Ten of Spermatophytes are in subdivision Gymnospermae and 484 of them are in subdivision Angiospermae. 89 of Angiosperms are in class Liliopsida while 395 of them in class Magnoliopsida. The endemism ratio in the study area is $4.25 \%$ (22 taxa). Phytogeographic elements are listed in order as: multiregional-unknown phytogeography root $47.4 \%$ (245), EuroSiberian 47.2\% (244), Irano-Turanian 2.1\% (11), and Mediterranean $3.3 \%$ (17). The life spectrum of taxa is as follows: Hemicryptophytes $48.7 \%$ (252), phanerophytes $16.1 \%$ (83), therophytes $15.7 \%$ (81), chamaephytes $10.4 \%$ (54), and cryophytes $9.1 \%$, (47). The richest families in taxa are Asteraceae (52), Poaceae (35), Rosaceae (31), Fabaceae (25), and Lamiaceae (24). In the study area 22 taxa were found as threatened taxa at different threatened levels. The results of the study was compared with the results of 10 studies carried out in Rize and neighboring cities.
\end{abstract}

\section{Handüzü Tabiat Parkı ve Çevresinin Floristik Çeşitliliği, Türkiye}
ÖZET
Kaçkar Dağları silsilesinde korunan bir alan olarak, Rize (Türkiye)'nin, Güneysu ve İkizdere ilçelerinde bulunan Handüzü Tabiat Parkı ve çevresinin floristic çeşitliliği çalışılmıştır. 104 familyaya ait 352 cins ve 517 takson belirlenmiştir. Taksonlardan 23 tanesi Pteridophyta, 494 tanesi ise Spermatophyta bölümünde temsil edilmektedir. Spermatophyta bölümüne ait taksonlardan 10'u Gymnospermae, 484'ü ise Angiospermae alt bölümünde bulunur. Angiospermlerin 89'u Liliopsida sinıfindayken 395’i Magnoliopsida sinıfindadır. Taksonların endemizm oranı \%4.25 (22 takson) olarak belirlenmiştir. Çalışma alanındaki taksonların fitocoğrafya bölgelerine göre dağılımı; fitocoğrafik bölgesi bilinmeyenler \%47.4 (245), Avrupa-Sibirya \%47.2 (244), İran-Turan \%2.1 (11) ve Akdeniz \%3.31 (17)'dir. Taksonların hayat formları şu şekildedir: Hemikriptofitler \%48.7 (252), fanerofitler \% 16.1 (83), terofitler \%15.7 (81), kamefitler \%10.4 (54), and kriptofitler \%9.1 (47). Çalışma alanındaki en zengin taksonlu familyalar Asterceae (52), Poaceae (35), Rosaceae (31), Fabaceae (25) ve Lamiaceae (24)'dir. Çalışma alanındaki 22 takson, farklı tehlike kategorilerinde, tehlike altında bulunmuştur.

\section{Research Article}

$\begin{array}{ll}\text { Article History } & \\ \text { Received } & : 26.03 .2019 \\ \text { Accepted } & : 13.06 .2019\end{array}$

\section{Keywords}

Handüzü-Çağrankaya,

Güneysu,

Flora,

Rize,

Turkey

\section{Araştırma Makalesi}

Makale Tarihçesi
Geliş Tarihi : 26.03 .2019

Kabul Tarihi : 13.06 .2019

Anahtar Kelimeler
Handüzü-Çağrankaya,
Güneysu,
Flora,
Rize,
Türkiye

Türkiye

To Cite : Atamov V, Çobanoğlu M 2019. Floristic Diversity of Handüzü Natural Park and Environs, Turkey. KSU J. Agric Nat 22(Suppl 1): 84-90. DOI: 10.18016/ksutarimdoga.vi.544872

\section{INTRODUCTION}

The total number of plant species in the world is increasing day by day. According to Payne (2016) more than 250.000 plant species have been identified after binominal nomenclature concept of Linnaeus (1973). Maarten et al. (2016) reported that the total plant species of the world is ca 374.000 , of which 308.312 are 
in Spermatophyta division. Nowadays, the number of the new species, published per year, is ca 2.0000 (Lindon et al., 2015).

The first study on the Flora of Turkey, documented in 6 volumes, is Flora Orientalis (Boissier, 1865-1888). The second and the most detailed research on the Flora of Turkey, documented as 11 volumes, in which 8988 species were described, is Flora of Turkey and the East Aegean Islands (Davis, 1965-1985; Davis et al., 1988; Güner et al., 2000). Güner et al. (2012) published the Plant List of Turkey, Vascular Plants (Güner et al. 2012), in which 9996 species were described. After check list series of Özhatay et al. (2013), the total number of plant species in Turkey increased to 10169 while the total taxa number (with addition of subspecies, varieties and hybrids) increased to 11935 . Currentely, the total number of Turkish vascular plant taxa is over 12.000 and it continues to increase.

There have been some floristic studies in Rize (Güner 1987; Çobanoğlu 2012; Demir 2013; Baykal and Atamov 2016; Baykal and Atamov 2017; Baykal and Atamov 2018; Baykal et al. 2018) and in neighboring cities (Terzioğlu 1998; Palabaş-Uzun 2009; Uzun 2009; Eminağaoğlu 2003; Eminağaoğlu and Anşin 2004).

The study area covers Handüzü Natural Park and its environs. There is not any floristical study which is focused on only its flora that reflects all seasonal variations. The objective of this researchwas to determine the floristic diversity of this Natural Park and its environs.

\section{MATERIAL and METHODS}

Handüzü Natural Park is $16 \mathrm{~km}$ away from Rize city center in Turkey. The study area, Handüzü Natural Park and environs, lies between the latitudes $40^{\circ} 58^{\prime} 11^{\prime \prime}$ - 40 47' $54^{\prime \prime}$ and longitudes 40 $37^{\prime} 39^{\prime \prime}$ $40^{\circ} 42^{\prime} 55^{\prime \prime}$, contains two highlands. The first highland Handüzü is in the Güneysu district and the second one Çağrankaya is in the İkizdere district. According to Davis (1965-1985), the study area is at A8 square, in Colchic sector of Euro-Siberian floristic region. The study area is very mountainous and is deeply divided by the streams Taşlıdere, Paşacur, and Sel in the west and Kale and Güneysu in the east. The lowest part of the study area was $150 \mathrm{~m}$ just over Güneysu district and the highest part was $2700 \mathrm{~m}$ at Çağrankaya highland (Fig. 1).

The lower part of Handüzü Natural Park is geologically composed of Paleozoic and Cretaceous aged granodiorite, andesite and basalt and the higher parts, especially Çağrankaya highland, composed of upper Cretaceous aged lava, dasite, andesite (Gedik et al., 1992; Anonymous, 2000). The mountainous zones in the study area consist of scars and rifts while the rest parts contain 3 main soil types, namely red-yellow podzolic, calcareous brown forest and high mountain meadow soils (Anonymous, 2005).

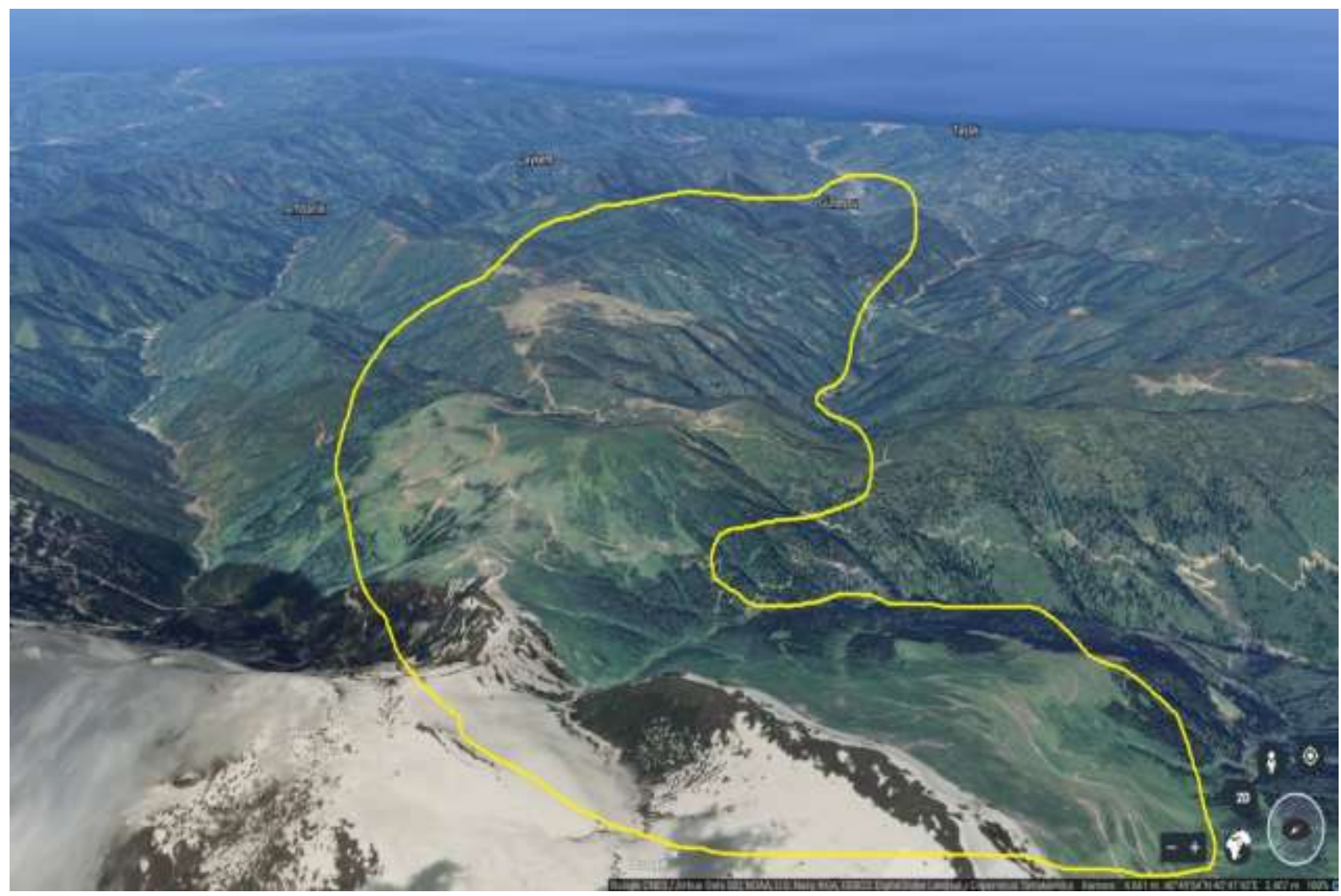

Fig. 1. The study area. 
There are elevational differences $(150-2700 \mathrm{~m})$ in the study area and as a result of these differences the climate from $150 \mathrm{~m}$ to $2000 \mathrm{~m}$ is very-humid, mesothermal, oceanic climate while from $2000 \mathrm{~m}$ to $2700 \mathrm{~m}$ very-humid, microthermal which reminiscent of continental climate. Both in Rize and study area, there is not any dry season and the precipitation regime is as autumn, winter, spring and summer (Au.Wi.Su.Si.). The annual mean precipitation in Rize, for last 20 years, is $2441 \mathrm{~mm}$ while the annual mean temperature is $14.9{ }^{\circ} \mathrm{C}$. (Anonymous, 2016). The climatic data of Rize station were interpolated for the altitude $2000 \mathrm{~m}$ and according to these values, in the study area, January, February, March, November and December are the frosty months while April is the probable frosty month (Fig. 2).

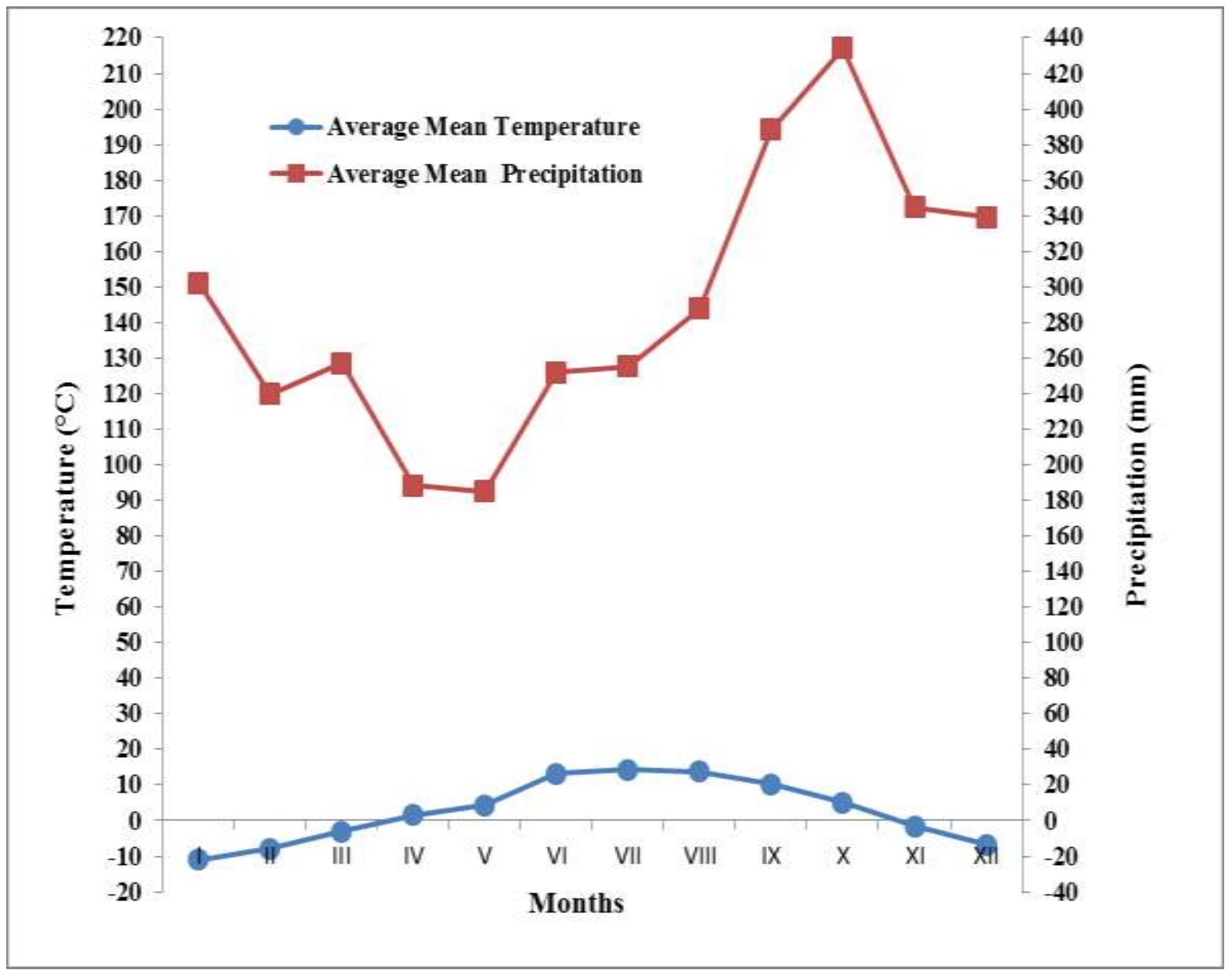

Figure 2. Interpolated climate diagram for Handüzü Natural Park and environs (for $2000 \mathrm{~m}$ )

The materials of the study were consist of 2000 vascular plant samples, which were collected from the study area during the vegetation periods of the years 2010-2011 and 2016. The plant materials were collected ensuring that they possess all vegetative and generative organs. The collected plant samples were dried out and stuck on cartons with modern herbarium rules (Seçmen et al., 2008). The herbarium materials of each taxon have been preserved at the herbarium of Biology Department, Faculty of Science and Arts, Recep Tayyip Erdoğan University. The Flora of Turkey and the East Aegean Islands, documented in 11 volumes (Davis, 1965-1985; Davis et al., 1988; Güner et al., 2000), was used to describe all taxa. The European (Tutin et al., 1964-1980) and Russian flora (Komarov and Shishkin, 1933-1964; Ketzkhoveli and
Gagnidze, 1971-2001) were also used in identification of taxa. Some more studies (Güner et al., 1987; Terzioğlu, 1998; Eminağaoğlu and Anşin, 2003, 2004; Uzun, 2009; Palabaş Uzun, 2009; Güner et al., 2012; Khan et al., 2011; Demir, 2013; Shaheen, 2014; Baykal, 2015) were followed, to checked the described taxa and to compare the results of the study. All described taxa were controlled with the herbarium samples of Karadeniz Technical and Hacettepe Universities. The family, taxa and author (Brummitt et al., 1992) name and localities of each taxon are given correspondingly. The endemism and phytogeography element status (Davis, 1965-1985; 1988; Güner et al., 2012), life spectrum (Raunkiaer, 1934; Ellenberg Mueller-Dombois, 1967) and threatened categories (Ekim et al., 2000), were also given. 


\section{RESULTS and DISCUSSION}

The results of the study, comparison and discussion, with the results of 10 studies (FVP., FEV., FCP., FVU., FVS., FKN., MDB., FHN., FVT and FIN.) close to the research area are given below.

The vascular flora of Handüzü Natural Park and Environs consist of 517 taxa, of which 412 species, 84 subspecies and 21 varieties within 352 genera and 104 families. 494 of these taxa are Spermatophyte while 23 remainders are Pteridophyte. Gymnospermae subdivision is represented by 10 taxa. Overall, 484 of the total taxa are within Angiospermae (Table 1).

Angiosperms divided as 395 Dicotyledones and 89 Monocotyledones. The total taxa number of the study (517) is richer than the total taxa number in the studies FCP. (228), FVT (408) and FVS. (479), while it is nearly equal to FEV. (518) (Table 2). On the other hand, it is smaller than the studies MDB. (656), FHN. (769), FKN. (853), FVU. (1024), and FVP. (1430) (Table 2).

The differences in the total taxa number of the compared studies can be explained with the size of the study areas, habitat diversity, edaphic factors, etc. The Euro-Siberian phytogeography elements are very rich in the study area with $244(47.2 \%)$ taxa (Table 2 ). The
Mediterranean phytogeography elements follow them with $17(3.3 \%)$ taxa and finally Irano-Turanian elements with $11(2.1 \%)$ taxa. $245(47.4 \%)$ taxa are multi regional or unknown phytogeographic root (Table 2). The study area is under the influence of the Euro-Siberian phytogeography province, which can explain the dominancy of the Euro-Siberian phytogeography element. The presence of the Mediterranean and Irano-Turanian phytogeography elements in the study area can be clarify by the microclimates in Handüzü Natural Park and Environs. Also, 13 (2.5\%) endemics are Euro-Siberian phytogeography elements, $1(\% 0.2)$ endemic is Mediterranean and $2(0.4 \%)$ endemics are IranoTuranian phytogeography elements (Table 3). Even though the Euro-Siberian phytogeography region elements are in the first place in all studies (FVP., FEV., FCP., FVU., FVS., FKN., MDB., FHN and FVT.) and Irano-Turanian phytogeography region elements are in the second place, only in this study, with a few majority, Mediterranean phytogeography region elements are in the second place (Table 2). This is an expected result because, all Eastern Black Sea region is in the borderlines of Euro-Siberian phytogeography province.

Table 1. The distribution of taxa in upper taxonomic categories.

\begin{tabular}{llllllll}
\hline & Family & Genus & Species & Subspecies & Variety & Taxa & Endemics \\
\hline Pteridophyta & 10 & 13 & 18 & 5 & - & 23 & - \\
Spermatophyta & 94 & 339 & 394 & 79 & 21 & 494 & 22 \\
Gymnospermae & 3 & 7 & 5 & 4 & 1 & 10 & - \\
Angiospermae & 91 & 332 & 389 & 75 & 20 & 484 & 22 \\
Dicotyledones & 78 & 274 & 312 & 64 & 19 & 395 & 19 \\
Monocotyledones & 13 & 58 & 77 & 11 & 1 & 89 & 3 \\
Total & 104 & 352 & 412 & 84 & 21 & 517 & 22 \\
\hline
\end{tabular}

Table 2. Phytogeography element comparison.

\begin{tabular}{|c|c|c|c|c|c|c|}
\hline Researches & Euro- Siberian & Mediterrenean & Irano Turanian & $\begin{array}{l}\text { Cosmopolite } \\
\text { other }\end{array}$ & and Taxa & Endemic \\
\hline FDH. & 47.2 & 3.3 & 2.1 & 47.4 & 517 & 4.3 \\
\hline FVP. & 48.2 & 3.0 & 5.7 & 43.0 & 1430 & 18.5 \\
\hline FEV. & 43.2 & 2.1 & 4.1 & 50.6 & 518 & 7.0 \\
\hline FCP. & 67.5 & 0 & 2.2 & 29.3 & 228 & 5.3 \\
\hline FVU. & 41.1 & 2.0 & 4.6 & 5.3 & 1024 & 7.1 \\
\hline FVS. & 49.5 & 1.3 & 2.3 & 46.9 & 479 & 4.2 \\
\hline FKN. & 39.4 & 1.2 & 10.3 & 49.1 & 853 & 6.3 \\
\hline MDB. & 43.9 & 3.4 & 4.0 & 48.8 & 656 & 5.2 \\
\hline FHN. & 35.6 & 2.2 & 6.9 & 55.3 & 769 & 7.4 \\
\hline FVT. & 58.1 & 1.2 & 3.4 & 37.3 & 408 & 4.9 \\
\hline
\end{tabular}

FDH.: Floristic Diversity of Handüzü Natural Park and Environs, Turkey, current study; FVP.: Flora,Vegetation and Polen Analysis of Rize, Guner et al., 1987; FEV.: Flora Vegetation and Enthnobothy of Başhemşin (Çamlıhemşin, Rize), Baykal and Atamov, 2016; FCP.: Ayder-Çeymakçur (Çamlıhemşin/Rize) plateau flora and the chemical and polynological properties of local honeys., Demir, 2013; FVU.: Flora and Vegetation of Uzungöl (Çaykara, Trabzon), Terzioglu, 1998; FVS.: Flora, Vegetation and Succession of Sisdağı (Trabzon), Palabas Uzun, 2009; FKN.: Flora of the Karagol-Sahara National Park (Artvin) and Its Environs, Eminagaoglu and Ansin, 2004; MDB.: Maping and Determination of plant biodiversty of KTU Universty Research Forest (Trabzon), Uzun, 2009; FHN.: Flora of Hatila Valley National Park (Artvin) and its Close Environs, Eminagaoglu and Ansin, 2003; FVT.:Flora of Tunca Valley Natural Park and Environs, Baykal et al., 2018 
Table 3. Analogy of phytogeography elements, threatened status, endemic nonendemic.

\begin{tabular}{|c|c|c|c|c|c|c|}
\hline \multirow{2}{*}{ Phytogeographic regions } & \multicolumn{2}{|l|}{ Endemic } & \multicolumn{2}{|c|}{ Nonendemic } & \multicolumn{2}{|l|}{ Sum } \\
\hline & Number & Ratio\% & Number & Ratio\% & Number & Ratio\% \\
\hline Euro-Siberian & 13 & 2.5 & 231 & 44.7 & 244 & 47.2 \\
\hline Mediterranean & 1 & 0.2 & 16 & 3.1 & 17 & 3.3 \\
\hline Irano-Turanian & 2 & 0.4 & 9 & 1.7 & 11 & 2.1 \\
\hline Cosmopolite and others & 6 & 1.2 & 239 & 46.2 & 245 & 47.4 \\
\hline Total & 22 & 4.3 & 495 & 95.7 & 517 & 100 \\
\hline Endangered (EN) & 4 & 0.8 & & & 4 & 0.8 \\
\hline Near threatened (NE) & 4 & 0.8 & & & 4 & 0.8 \\
\hline Vulnerable (VU) & 4 & 0.8 & & & 4 & 0.8 \\
\hline Least concern (LC) & 10 & 1.9 & & & 10 & 1.9 \\
\hline Sum & 22 & 4.3 & & & 22 & 4.3 \\
\hline
\end{tabular}

In the study area 22 threatened taxa, all them are endemic, were determined (Table 3). Also, 4 endemic is listed in EN, 4 endemics in NE, 4 endemics in VU and 10 endemics are in LC (Table 3). The number of threatened taxa in compared studies, the threatened taxa data were available, are as follow; MDB. 42, FVS. 30, FKN. 30, FEV. 13 and FCP. 12. 22 endemic taxa were determined in the research area (Table 2). The endemism ratio of the study and compared studies are given in Table 3. The endemism ratio of the studies was generally focus around 7\% (FEV., FKN., FVU. and FHN.), and 5\% (FCP., FDH., FVT., and MDB). Only RF differs from the others with the endemism ratio of (18.5\%). In these studies, the homogeneity of climate and environmental similarities may be the reasons of low endemism ratio.

The richest families of the study area in taxa numbers are Asteraceae (52), Poaceae (35), Rosaceae (31), Fabaceae (25), and Lamiaceae (24) (Table 4).

The family Poaceae is the second richest family about the total taxa numbers in the studies FVG., FEV., FVP., and MDB., which overlaps with large meadow areas within their boundaries (Table 5). There is a harmony, with small differences, in the series of the other families about the total taxa numbers.

The genera rich families are: Asteraceae (37), Poaceae (25), Rosaceae (21), Fabaceae (17), Lamiaceae (16) (Table 6).

The life-form data of the taxa in the studies FVG., FEV., FCP., and FIN., of which life-form information of the taxa are available, are given in Table 7 . The life spectrum of the taxa in the study FVG is: hemicryptophytes 252 (48.7\%), phanerophytes 89 $(17.2 \%)$, therophytes $84(16.3 \%)$, chamaephytes 54 (10.5\%), cryptophytes $47(9.1 \%)$. In the studies compared, hemicryptophytes are the richest life-form: FEG. (252), FEV. (229), FVG. (143) and, FIN (94). This is correlated with large amount of subalpine and alpine vegetation in the study areas. The size of forest vegetation in Handüzü Natural Park is larger than the researches of FEV. and FCP. Hence, the phanerophytes in FVG. (83) are more than the studies FCP. (31), FIN (29) and FEV. (17) (Table 8).

Table 4. The richest 5 families about genera.

\begin{tabular}{lll}
\hline Family & Genus & Ratio $(\%)$ \\
\hline Asteraceae & 37 & 10.5 \\
Poaceae & 25 & 7.1 \\
Rosaceae & 21 & 6.0 \\
Fabaceae & 17 & 4.8 \\
Lamiaceae & 16 & 4.5 \\
Total & 116 & 32.9 \\
\hline
\end{tabular}

In Turkey, according to total taxa numbers, Asteraceae is the richest family; thus, all of the studies compared (FVG., FVP., FEV., FCP., FVU., FVS., FKN. and MDB.), except FHN. and FIN., are compatible with Flora of Turkey (Table 5).

Table 5. The analogies of rich families about taxa.

\begin{tabular}{ll|l|l|l|l|l|l|l|l|l}
\hline Family & \multicolumn{9}{l}{ Compared studies (\%) } & \multicolumn{10}{ll}{$l$} \\
& FVG. & FVP. & FEV. & FCP. & FVU & FVS. & FKN. & MDB. & FHN. & FIN. \\
\hline Asteraceae & 10.1 & 12.5 & 10.9 & 10.5 & 13.8 & 10.9 & 11.4 & 11.4 & 9.8 & 8.0 \\
Poaceae & 6.8 & 10.7 & 9.7 & 3.5 & 5.5 & 6.1 & 7.5 & 7.3 & 2.5 & 10.5 \\
Rosaceae & 6.0 & 5.0 & 5.2 & 6.6 & 6.0 & 7.9 & 6.7 & 6.1 & 5.9 & 5.0 \\
Fabaceae & 4.8 & 4.8 & 5.4 & 3.9 & 6.5 & 6.3 & 9.4 & 6.3 & 10.2 & 5.5 \\
Lamiaceae & 4.6 & 4.7 & 4.2 & 5.3 & 4.8 & 5.4 & 5.8 & 5.0 & 5.9 & 6.0 \\
\hline
\end{tabular}

FIN: Flora of Isırlık Natural Park and Environs 
Table 6. The richest 5 families about genera.

\begin{tabular}{lll}
\hline Family & Genus & Ratio $(\%)$ \\
\hline Asteraceae & 37 & 10.5 \\
Poaceae & 25 & 7.1 \\
Rosaceae & 21 & 6.0 \\
Fabaceae & 17 & 4.8 \\
Lamiaceae & 16 & 4.5 \\
Total & 116 & 32.9 \\
\hline
\end{tabular}

Table 7. The taxonomic diversity and floristic richness.

\begin{tabular}{l|l|l|l|l|l|l|l|l|l}
\hline & \multicolumn{10}{c}{ Compared studies } \\
\cline { 2 - 11 } & FVG. & FVP. & FEV. & FCP. & FVU. & FVS. & FKN. & MDB. & FHN. \\
\hline Species (T) & 517 & 1430 & 518 & 228 & 1024 & 479 & 863 & 656 & 769 \\
Genus (G) & 352 & 555 & 228 & 131 & 435 & 259 & 364 & 354 & 374 \\
Family (F) & 104 & 130 & 74 & 48 & 117 & 82 & 91 & 95 & 95 \\
T/G & 1.8 & 2.6 & 2.0 & 1.7 & 2.4 & 1.8 & 2.4 & 1.8 & 2.1 \\
G/F & 3.9 & 4.3 & 3.5 & 2.7 & 3.7 & 3.1 & 4.0 & 3.7 & 3.9 \\
\hline
\end{tabular}

The taxonomic diversity and floristic richness of Handüzü Natural Park and environs are given in Table 7. Even though there are some little differences there is a concordance in taxonomic diversity and floristic richness in the compared studies. The study (FVG.) has an equal taxonomic diversity and floristic richness (1.8\%) with the studies MDB.(1.8\%) and FVS. $(1.8 \%)$.
It has a richer taxonomic diversity and floristic richness than FCP. (1.7\%) and lesser than the studies FVP. (2.6), FEV. (2.0), FVU. (2.4), FKN. (2.4) and FHN. (2.1). G/F $(3.9 \%)$ value of the study is higher than that of FEV. (2.7\%), FCP. (2.7\%), FVU. (3.7\%), FVS. (3.1\%) and MDB. (3.7\%) equal to FHN. and lower than FVP. (4.3\%) and FKN. (4.0\%) (Table 7).

Table 8. The comparative life spectrum of compared studies.

\begin{tabular}{lllllllll}
\hline Studies & Hcrp. & Php. & Thp. & Chp. & Crp. & NanoPh. & Vp. & Hd. \\
\hline FVG. & 252 & 83 & 81 & 54 & 47 & - & - & - \\
FEV. & 229 & 17 & 62 & 57 & 145 & 3 & 2 & 1 \\
FCP. & 143 & 31 & 16 & 16 & 31 & - & - & - \\
FIN. & 94 & 29 & 38 & 6 & 34 & - & - & - \\
\hline
\end{tabular}

Hcrp.: Hemicryptophytes; Php.: Phanerophytes; Thp.: Therophytes; Chp.: Chamaephytes; Crp.: Cryptophytes; NanoPh.: Nanophanerophytes; Vp.: Vasicular parasite; Hd.: Hydrophytes.

\section{REFERENCES}

Anonymous 2000. 1/500000 Ölçekli Türkiye Jeoloji Haritaları. Mad en Tetkik ve Arama Genel Müdürlüğü Press, Ankara.

Anonymous 2005. Rize İli Arazi Varlı̆̆ı.T.C. Tarım ve Köyişleri Bakanlığı, Köy Hizmetleri Genel Müdürlüğü, İl Rapor No: 53, Ankara.

Anonymous 2011. 1975-2010 Dönemi Pazar Meteoroloji İstasyonuna Ait Rasat Değerleri. Devlet Meteoroloji İşleri Genel Müdürlüğü Press., Ankara.

Baykal H, Atamov V 2016. Floristic Diversity in Bashemsin Valley of Kackar Mountains National Park of Rize, Turkey. Pakistan Journal of Botany, 48 (5):1871-1876.

Baykal H, Atamov V 2017. Ethnobotanical Documentation of Plants of Başhemşin Valley, Kaçkar Mountains National Park, Rize, Turkey. Bangladesh Journal of Botany, 46 (2):767-773.

Baykal H, Atamov V 2018. Isırlık Doğa Parkı ve Çevresinin Florası. Ot Sistematik Botanik Dergisi, 25(2): 151-170.
Baykal H, Atamov V, Yüksek T 2018. Flora of Tunca Valley Natural Park and Environs (ArdeşenRize/Turkey). Biological Diversity and Conservation, 11(3):9-23.

Boissier PE 1865-1888. Flora Orientalis. H.George Press., Basel.

Brummitt RK, Powell CE (eds.) 1992. Authors of Plant Names. Royal Botanic Gardens, Kew, 732 pp.

Christenhusz MJM, Byng JW 2016. The number of known plants species in the world and its annual increase. Phytotaxa, 261(3): 201-217.

Çobanoğlu M 2012. Flora and Vegetation of GüneysuÇağrankaya (Güneysu, Rize). RTEU. Institute of Science and Technology, Master Thesis, 153pp.

Davis PH (eds.) 1965-1985. Flora of Turkey and the East Aegean Islands. Vols. 1-9, Edinburgh University Press, Edinburgh.

Davis PH, Mill RR, Tan K (eds.) 1988. Flora of Turkey and the East Aegean Islands. Vol. 10, Edinburgh University Press, Edinburgh.

Demir E 2013. Ayder-Çeymakçur (Çamlıhemşin/Rize) plateau flora and the chemical and polynological 
properties of local honeys. RTEU. Institute of Science and Technology, Master Thesis, 130pp.

Ekim T, Koyuncu M, Vural M, Duman H, Aytaç Z, Adiguzel N 2000. (Red Data Book of Turkish Plants, Pteridophyta and Spermatophyta). TTKD Van Yuzuncuyll Universitesi Press, Ankara, 246pp.

Ellenberg H, Mueller-Dombois D 1967. A key to Raunkiaer plant life forms with revised subdivisions. Ber. Geobot. Inst ETH Stiftg Rubel Zurich, 37: 56-73.

Eminagaoglu O, Ansin R 2003. The flora of Hatila Valley National Park and its close environs (Artvin). Turk. J. Bot., 27: 1-27.

Eminagaoglu O, Ansin R 2004. Flora of the KaragolSahara National Park (Artvin) and its environs. Turk. J. Bot., 28: 557-590.

Gedik AT, Korkmaz S, Karatas S 1992. Rize-FındıklıÇamlıhemşin Arasında (Doğu Karadeniz) Yer Alan Magmatik Kayaçların Petrolojisi ve Doğu Pontitlerdeki Bölgesel Yayılımları. Türkiye Jeoloji Bülteni, 35: 15-38.

Guner A 1984. Rize Florasına Hazırlık I Rize'den bitki toplayanların listesi. Doğa Turk. J. Bot., 8 (2): 278281.

Guner A, Vural M, Sorkun K 1987. Rize Florası, Vejetasyonu ve Yöre Ballarının Polen Analizi. Tübitak Matematik, Fizik ve Biyolojik Bilimler Araştırma Grubu, Proje No: TBAG-650, Ankara, Türkiye.

Guner A, Ozhatay N, Ekim T, Baser KHC (eds.) 2000. Flora of Turkey and the East Aegean Islands. Vol. 11. Edinburgh University Press, Edinburgh.

Guner A, Aslan S, Ekim T, Vural M, Babac MT (eds.). 2012. Türkiye Bitkileri Listesi (Damarlı Bitkiler). Nezehat Gökyiğit Botanik Bahçesi Press, İstanbul.

Ketzkhoveli NN and Gagnidze RI (eds.) 1971-2001. Georgian Flora (Flora of Georgia). Vols. 1-13. Metsniereba, Tbilisi, Georgia.

Khan SM, Harper DM, Page S, Ahmad H 2011. Species and Community Diversity of Vascular Flora along Environmental Gradient in Naran Valley: A
Multivariate approach through Indicator Species Analysis. Pak. J. Bot., 43 (5): 2337-2346.

Komarov VL, Shishkin BK (eds.) 1933-1964. Flora of USSR (English translation) Vols. 1-30, Akademiya Nauk SSSR., Moscow and Leningrad.

Lindon H, Heater L, Bradly A, Vorontsova M 2015. Fewer than three percent of land plants named by women: author gender over 260 years. Taxon, 64: 209-215.

Özhatay N, Kültür Ş, Gürdal B 2013. Check List of Additional Taxa to the Supplement Flora of Turkey VI. İstanbul Ecz. Fak. Derg., 43(1): 33-82.

Palabas Uzun S 2009. Flora, Vegetation and Succession of Sisdağ (Trabzon). KTU. Institute of Science and Technology, Phd. Thesis, 213pp.

Payne A 2016. Why do taxonomists write the meanest obituaries? The open nature of the science of classification virtually guarantees fights. Nautilus 35 .

Raunkiaer C 1934. The Life Form of Plants and Statistical Plant Geography. Oxford University Press., London, 632pp.

Seçmen O, Gemici Y, Leblebici E, Gork G, Bekat L 2008. Tohumlu Bitkiler Sistematiği. Ege Üniversitesi Press, İzmir, 240pp.

Shaheen H, Rahmatullah Q, Iram Z, Munir M, Ilyas M 2014. Floristic Diverstyof Santh Saroola, Kotli Sattia, Rawalpindi, Pakistan. Pak. J. Bot., 46(6): 19945-1954.

Terzioğlu S 1998. Flora and Vegetation of Uzungöl (Çaykara, Trabzon). KTU Institute of Science and Technology, Phd. Thesis,308pp.

Tutin, TG, Heywood VH, Burges NA, Moore DM, Valentine DH, Walters S and Webb BA (eds.) 19641980. Flora Europaea. Vols. 1-5. Cambridge University Press., Cambridge.

Uzun A 2009. Maping and Determination of plant biodiversty of KTU Universty Research Forest (Trabzon). KTU Institute of Science and Technology, Phd. Thesis, 303pp. 